\title{
Pengantar editor-in-chief Mediapsi volume 7 nomor 1 tahun 2021
}

\author{
Ali Mashuri ${ }^{(1)}$ \\ ${ }^{(1)}$ Jurusan Psikologi, Universitas Brawijaya, Malang, Indonesia
}

\begin{abstract}
Mediapsi published 7 empirical articles for its new edition, i.e., volume 7 issue 1, 2021, which cover multifarious topics and research methods. The first article is qualitative research aimed at investigating the self-adjustment of a postgraduate who works while studying. The second article focuses on undergraduate students' academic burnout and explained quantitatively this phenomenon based on various forms of social support. The third article is meta-analysis research to synthesize the extent to which mindfulness-based interventions are effective in increasing resilience at the workplace. The fourth article applied a qualitative method that also touches upon the topic of resilience but within a different context, that is, community resilience amid the COVID-19 pandemic. The fifth article, the same as the third article, is meta-analysis research to examine to what extent music therapy has a significant effect as an intervention in improving sleep quality. The sixth article is an experimental research that tested the effect of virtual reality on the induction of negative emotions. The seventh, last article also examined the phenomenon of social support explained its role in explaining subjective well-being among a sample of ethnic Minang adolescents.
\end{abstract}

Keywords: academic burnout, community resilience, mindfulness intervention, social support, subjective well-being, virtual reality

Dalam volume 7 nomor 1 tahun 2021 ini, Mediapsi mempublikasikan tujuh artikel empiris dengan topik dan metode penelitian yang bervariasi. Artikel pertama menerapkan metode kualitatif untuk meneliti adaptasi atau penyesuaian-diri mahasiswa yang kuliah sambil bekerja. Artikel kedua mengangkat tema atau topik tentang academic burnout di kalangan mahasiswa yang dijelaskan secara kuantitatif atas dasar berbagai bentuk social support. Artikel ketiga merupakan studi meta-analisis untuk menguji sejauh mana intervensi berbasis mindfulness efektif untuk meningkatkan resiliensi di tempat kerja. Artikel keempat menerapkan metode kualitatif yang juga membahas topik tentang resiliensi tetapi dalam konteks yang berbeda, yaitu resiliensi komunitas di tengah pandemi COVID-19. Artikel kelima, seperti artikel ketiga, adalah studi metaanalisis yang bertujuan untuk menyimpulkan sejauh mana musik terapi berpengaruh signifikan sebagai intervensi dalam meningkatkan kualitas tidur. Artikel keenam merupakan riset eksperimen yang menguji sejauh mana virtual reality berpengaruh dalam menginduksi emosi-emosi negatif. Artikel ketujuh sekaligus terakhir juga meneliti dukungan sosial atau social support dan menguji perannya terhadap subjective wellbeing di kalangan remaja etnis Minang.

Kata kunci: academic burnout, dukungan sosial, intervensi mindfulness, resiliensi komunitas, subjective wellbeing, virtual reality

MEDIAPSI, 2021, Vol. 7(1), 1-4, DOI: https://doi.org/10.21776/ub.mps.2021.007.01.1

Published online: 24-06-2021

*Corresponding author: Ali Mashuri, Jurusan Psikologi, Fakultas Ilmu Sosial dan Ilmu Politik, Universitas Brawijaya, Malang,

Indonesia.. E-mail: alimashuri76@ub.ac.id

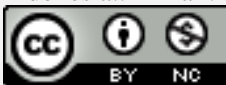

This work is licensed under a Creative Commons Attribution-NonCommercial 4.0 International License.

How to cite this article in accordance with the American Psychological Association (APA) $6^{\text {th }}$ guidelines:

Mashuri, A. (2021). Pengantar editor-in-chief Mediapsi volume 7 nomor 1 tahun 2021. MEDIAPSI, 7(1), 1-4. https://doi.org/10.21776/ub.mps.2021.007.01.1

Setahun lebih hingga Juni 2021 ini, semenjak pemerintah Indonesia secara resmi mengakui infeksi COVID-19 di Indonesia
Maret 2020 sebagai darurat kesehatan nasional (Ihsanuddin, 2020), pandemi penyakit baru tersebut belum juga selesai. Terlepas adanya 
berbagai hambatan dan kesulitan akibat belum selesainya pandemi COVID-19, kami telah berupaya sebaik dan semaksimal mungkin menerbitkan tujuh artikel empiris dalam edisi terbaru ini: Mediapsi volume 7, nomor 1, tahun 2021.

Artikel pertama mengangkat topik atau tema tentang penyesuaian diri (self-adjustment) pada diri seorang mahasiswa yang sedang menempuh studi magister sambil bekerja. Secara umum, fenomena ini disebut sebagai mahasiswa paruh-waktu atau part-time student, yang mengalami trend peningkatan baik di luar negeri (Nga, 2020) maupun di Indonesia ("Mahasiswa yang bekerja sambil kuliah meningkat", 2015) akibat, salah satunya, tantangan ekonomi yang semakin kompetitif. Riset kualitatif dalam artikel pertama yang ditulis oleh Lusi (2021) tersebut menemukan bahwa mahasiswa yang kuliah sambil bekerja harus melakukan penyesuaian-diri kognitif maupun emosional, untuk menghadapi peran ganda mereka sebagai mahasiswa sekaligus sebagai pekerja.

Artikel kedua, ditulis oleh Fun dkk. (2021), berfokus pada fenomena academic burnout di kalangan mahasiswa. Academic burnout merupakan tema klasik yang tetap saja relevan akibat prevalensi permasalahan tersebut di kalangan mahasiswa di era saat ini (Rahmatpour, 2019). Artikel kedua tersebut bertujuan untuk menguji peran beberapa bentuk social support atau dukungan sosial dalam mengurangi academic burnout mahasiwa. Hasil dalam artikel kedua menunjukkan bahwa belonging dan appraisal adalah bentuk social support yang berkontribusi signifikan, sementara tangible social support tidak berkontribusi signifikan dalam mengurangi academic burnout.

Artikel ketiga ditulis oleh Putri dan Yudiarso (2021) untuk meneliti resiliensi di tempat kerja. Resiliensi secara garis besar diasumsikan dan ditemukan meningkatkan kemampuan adaptasi individu dalam menghadapi kesulitan dan tantangan kehidupan MEDIAPSI | 2021, Vol. 7, No. 1, 1-4
(Fisher dkk., 2019). Dalam konteks dunia kerja, resiliensi juga telah teruji sebagai salah satu faktor penentu kesuksesan karier individu yang bisa ditingkatkan melalui beberapa intervensi (Vanhove dkk., 2016). Menggunakan metaanalisis, artikel ketiga menyimpulkan bahwa mindfulness merupakan salah satu bentuk intervensi sosial yang tidak signifikan dalam meningkatkan resiliensi di tempat kerja.

Ditulis oleh Sunarno dan Sulistyowati (2021), artikel keempat juga membahas resiliensi tetapi menyelidiki topik ini dalam konteks yang berbeda. Secara lebih spesifik, artikel keempat berfokus pada resiliensi komunitas dalam menghadapi pandemi COVID-19. Resiliensi komunitas menjadi salah satu isu kontemporer dalam konteks pandemi COVID-19 akibat relevansi konsep tersebut dengan, dan juga pentingnya konsep tersebut bagi peningkatan kemampuan masyarakat untuk mampu bertahan menghadapi krisis akibat penyakit menular tersebut (Hou dkk., 2021). Artikel keempat menemukan bahwa nilai gotong-royong dan musyawarah, serta perilaku sosial ketetanggaan dan kepatuhan merefleksikan warisan sosial-budaya yang berkontribusi meningkatkan resiliensi komunitas di tengah pandemi COVID-19.

Artikel kelima merupakan studi metaanalisis, ditulis oleh Prayudi dan Yudiarso (2021), untuk menguji efektivitas musik terapi dalam meningkatkan kualitas tidur. Harus diakui, kualitas tidur merupakan permasalahan global yang dialami oleh individu di berbagai macam belahan dunia dan yang membawakan dampak negatif bagi kesehatan fisik maupun kesehatan mental (Chattu, 2019). Hasil penelitian artikel kelima menunjukkan bahwa musik terapi merupakan intervensi sosial yang efektif dalam meningkatkan kualitas tidur.

Artikel keenam, ditulis oleh Ali dkk. (2021), merupakan riset eksperimen dengan tujuan menguji peran virtual reality dalam menginduksi emosi-emosi negatif. Virtual reality menjadi fenomena kontemporer yang 
perlu dievaluasi dan direspon secara hati-hati, mempertimbangkan potensi dampak negatifnya bagi kesehatan mental individu (Freeman, 2017). Artikel keenam melaporkan bahwa virtual reality terbukti signifikan dalam menginduksi emosi negatif, khususnya emosi marah. Artikel ketujuh sekaligus terakhir ditulis oleh Pramisya dan Hermaleni (2021), yang menemukan signifikansi peran social support dalam menjelaskan subjective well-being pada remaja etnis Minang.

\section{Daftar Pustaka}

Ali, F., Grasiaswaty, N., \& Triman, A. (2021). Virtual reality sebagai penginduksian emosi negatif. MEDIAPSI, 7(1), 63-75. https://doi.org/10.21776/ub.mps.2021.007 .01 .7

Chattu, V. K., Manzar, M. D., Kumary, S., Burman, D., Spence, D. W., \& PandiPerumal, S. R. (2019). The global problem of insufficient sleep and its serious public health implications. Healthcare, 7(1), Article 10.3390. https://doi.org/10.3390/healthcare701000 1

Fisher, D. M., Ragsdale, J. M., \& Fisher, E. C. (2019). The importance of definitional and temporal issues in the study of resilience. Applied Psychology, 68(4), 583-620.

https://doi.org/10.1111/apps.12162

Freeman, D., Reeve, S., Robinson, A., Ehlers, A., Clark, D., Spanlang, B., \& Slater, M. (2017). Virtual reality in the assessment, understanding, and treatment of mental health disorders. Psychological Medicine, 47(14), 2393-2400. https://doi.org/10.1017/s00332917170004 $0 \mathrm{x}$

Fun, L. F., Kartikawati, I. A. N., Imelia, L., \& Silvia, F. (2021). Peran bentuk social support terhadap academic burnout pada mahasiswa Psikologi di Universitas " $\mathrm{X}$ " Bandung. MEDIAPSI, 7(1), 17-26. https://doi.org/10.21776/ub.mps.2021.007 .01 .3

Hou, W. K., Tong, H., Liang, L., Li, T. W., Liu, H., Ben-Ezra, M., ... \& Lee, T. M. C. (2021). Probable anxiety and components of psychological resilience amid COVID19: A population-based study. Journal of Affective Disorders, 282, 594-601. https://doi.org/10.1016/j.jad.2020.12.127

Ihsanuddin. (2020, 31 Maret). Jokowi tetapkan status darurat kesehatan masyarakat. Kompas.com.

https://nasional.kompas.com/read/2020/0 3/31/15265391/jokowi-tetapkan-statusdarurat-kesehatan-masyarakat

Lusi, R. A. (2021). Penyesuaian diri mahasiswa yang kuliah sambil bekerja. MEDIAPSI, $7(1)$, https://doi.org/10.21776/ub.mps.2021.007 .01 .2

Mahasiswa yang bekerja sambil kuliah meningkat. (2015, 10 Agustus). Cnn.com. https://www.bbc.com/indonesia/majalah/2 015/08/150810_majalah_pendidikan_mah asiswa

Nga, H. T. (2020). Demand for part-time job of students today. International Journal of Contemporary Research and Review, 11(09), 21746-21749. https://doi.org/10.15520/ijcrr.v11i09.846

Pramisya, R., \& Hermaleni, T. (2021). Kontribusi dukungan sosial terhadap subjective well-being pada remaja dari keluarga etnis Minang. MEDIAPSI, 7(1), 76-88.

https://doi.org/10.21776/ub.mps.2021.007 .01 .8

Prayudi, S. D., \& Yudiarso, A. (2021). Efektivitas musik terapi untuk meningkatkan kualitas tidur: Studi meta analisis. MEDIAPSI, 7(1), 53-62. https://doi.org/10.21776/ub.mps.2021.007 .01 .6

Putri, N. M. W. W. A., \& Yudiarso, A. (2021). Efektivitas intervensi berbasis 
mindfulness dalam meningkatkan resiliensi di tempat kerja: Studi meta analisis. MEDIAPSI, 7(1), 27-36. https://doi.org/10.21776/ub.mps.2021.007 .01 .4

Rahmatpour, P., Chehrzad, M., Ghanbari, A., \& Sadat-Ebrahimi, S. R. (2019). Academic burnout as an educational complication and promotion barrier among undergraduate students: A cross-sectional study. Journal of Education and Health Promotion, 8, $1-5$. http://doi.org/10.4103/jehp.jehp_165_19

Sunarno \& Sulistyowati, E. (2021). Resiliensi komunitas di tengah pandemi Covid-19. MEDIAPSI, $\quad 7(1), \quad 37-52$. https://doi.org/10.21776/ub.mps.2021.007 .01 .5

Vanhove, A. J., Herian, M. N., Perez, A. L., Harms, P. D., \& Lester, P. B. (2016). Can resilience be developed at work? A meta-analytic review of resilience-building programme effectiveness. Journal of Occupational and Organizational Psychology,89(2), 278-307.

https://doi.org/10.1111/joop.12123 